\title{
Rainwater Harvesting for Urban Ecology: Mustafa Uysal Park Case
}

\author{
Orhun SOYDAN ${ }^{*} \quad$ Ahmet BENLIAY ${ }^{1}$ \\ 'Akdeniz University Agriculture Faculty Landscape Architecture Department, Antalya \\ *Corresponding author e-mail (Sorumlu yazar e-posta) : orhunsoydan@akdeniz.edu.tr \\ Geliș tarihi (Received) : 5.04.2016 \\ Kabul tarihi (Accepted): 10.05.2016
}

\begin{abstract}
Management/conservation of stored water for optimum benefits can greatly enhance the effectiveness the ecological balance. Therefore Mustafa Uysal Park has been selected as study area for productivity of water harvesting in Antalya, Turkey. Water resources are being depleted quickly. Green areas in Antalya need more irrigation water in the summer due to climate. Therefore, the use of irrigation water from rainwater is very important. Because of these, Antalya was selected as study area. Estimated net runoff formula (rational method) has been used to determine water harvesting values for 12 months for study area. ArcHydro plugin in Arc-GIS is used to determine basins in the park. The needs of water for irrigation and evaporation value for the surfaces have been calculated. With the use of these values, the amounts of water which can be stored have been determined. The study shows that water harvesting of water sustainability. Rainfed production systems in public parks are important to maintain can save \% 20.81 irrigation water in Mustafa Uysal Park. The results show that rainwater harvesting method is great importance of in terms of ecology and management of water.
\end{abstract}

Key Words: Arc-GIS, surface runoff, urban ecology, water-harvesting, water management

\section{Kentsel Ekolojide Yağmur Suyu Hasadı: Mustafa Uysal Park Örneği}

Öz

Optimum fayda için depolanan suyun yönetimi, ekolojik dengenin korunmasında büyük ölçüde etkili olabilir. Bu yüzden Antalya ilinde bulunan Mustafa Uysal parkı, sulama sistemlerinde su hasadı yönteminin verimliğinin belirlenmesi amacıyla çalıșma alanı olarak seçilmiștir. Su kaynakları hızlı bir șekilde azalıyor. Antalya ilinden bulunan yeșil alanlar, iklimden dolayı yaz aylarda daha fazla sulama suyuna ihtiyaç duymaktadırlar. Bu yüzden yağmur sularının sulama suyundan kullanılması oldukça önemli bir konudur. Bu yüzden Antalya ili, çalıșma alanı olarak seçilmiștir. Ortalama yüzey akıșını belirlemede kullanılan formül (rasyonel yöntem), çalıșma alanı için 12 ay boyunca su hasadı değerlerini belirlemek için kullanılımıștır. Park içerisindeki havzaları belirlemek için Arc-GIS programı içerisinde olan Arc-Hydro eklentisi kullanılmıștır. İhtiyaç duyulan sulama miktarı ve mevsimlere göre meydana gelen buharlașma miktarları hesaplanmıștır. Bu değerlerin kullanımıyla, saklanabilir su miktarı belirlenmiștir. Çalıșma, suyun sürdürülebilirliğinin sağlanmasında, su hasadı yönteminin önemini göstermiștir. Parklarda yağmur sularının kullanımına dayanan sulama sistemleri oldukça önemlidir. Yapılan çalıșma sonucunda; Mustafa Uysal Parkı' nda yağmur sularının \% 20,81'inin kullanılabileceği belirlenmiștir. Bu sonuçlar yağmur suyu toplama yöntemi ekoloji ve su yönetimi açısından büyük önem sahip olduğunu göstermiștir.

Anahtar Kelimeler: Arc-GIS, yüzey akıșı, kentsel ekoloji, su hasadı, su yönetimi 


\section{INTRODUCTION}

Currently, of the 1.5 billion hectares of cropland worldwide, more than $80 \%$ depend on rainfall alone, contributing to at least two-thirds of global food production (Rockström et al., 2007; Scheierling, 2011). While the coverage of rainfed agriculture varies regionally in developing regions including Latin America and Sub-Saharan Africa more than 90 percent of cropland is rainfed. According to FAO, the population of the least developed countries in the world is still predominantly rural: nearly 70 percent reside in the countryside (FAOSTAT, 2012).

According to $\mathrm{FAO}$, the population of the least developed countries in the world is still predominantly rural nearly 70 percent reside in the countryside (FAOSTAT, 2012). Despite massive progress in reducing poverty in some parts of the world, over the past two decades - notably in East Asia - there are still about 1.4 billion people living on less than US \$1.25 a day, and close to 1 billion people currently suffer from hunger (Studer and Liniger, 2013).

The increase in urbanization, the increase of impervious surfaces and reduction of green areas influence water cycle. Therefore, water harvest very important in urban area for meet water needs especially in arid and semi-arid climates.

Landscape holding areas store water in the soil for direct use by the plants. Concave depressions planted with grass or plants serve as landscape holding areas, containing the water, increasing water penetration, and reducing flooding. Depressed areas can be dug out, and the extra soil used to berm (a bank of soil used to retain water) the depression. With the addition of berms, moats, or soil terracing, flat areas also can hold water. One holding area or a series of holding areas can be designed to fill and then flow into adjacent holding areas via spillways (outlets for surplus water) (Waterfall, 2004)

The aim of water harvesting is to collect runoff or groundwater from areas of surplus or where it is not used, store it and make it available, where and when there is water shortage. These results in an increase in water availability by either (Figure 1) impeding and trapping surface runoff, and (Figure 2) maximizing water runoff storage or trapping and harvesting sub-surface water. Water harvesting makes more water available for domestic, livestock and agricultural use by buffering and bridging drought spells and dry seasons through storage. (Studer and Liniger, 2013).

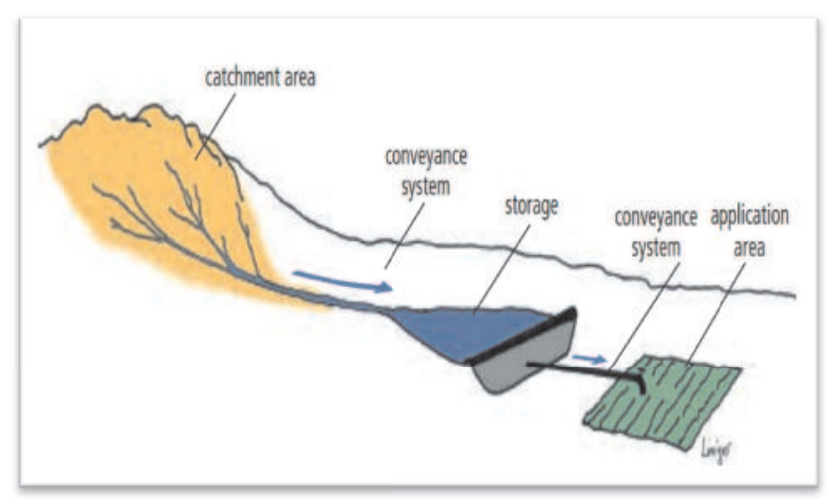

Figure 1. Catchment area, storage and application area are clearly separated and connected by conveyance systems (Studer and Lineger, 2013).

Sekil 1. Su toplama alanı, depolama ve uygulama alanları tașıma sistemleri tarafindan ayrılma ve bağlanmalarını gösteren kesit (Studer and Lineger, 2013).

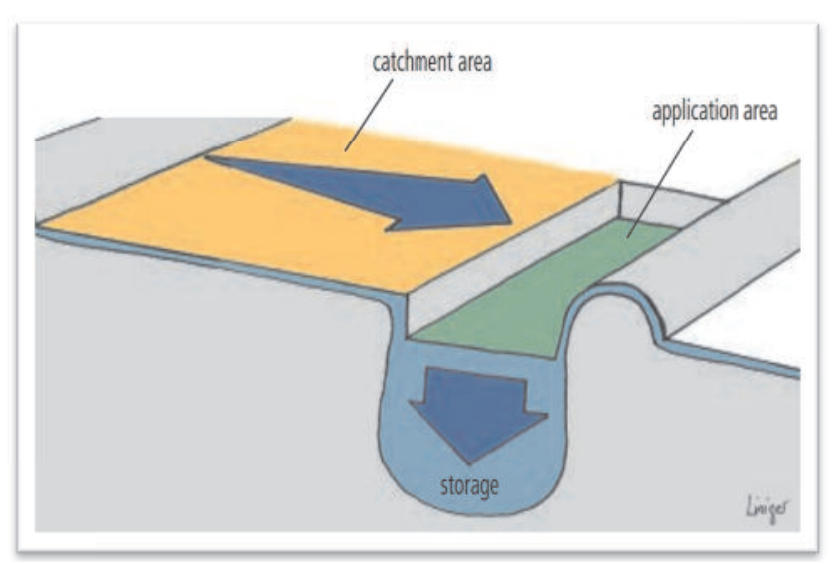

Figure 2. Catchment area is bordering application area (Studer and Lineger, 2013)

Șekil 2. Havza alanının uygulama alanı ile sınırlandııılığını gösteren kesit (Studer and Lineger, 2013).

Water harvesting is applied in arid and semi-arid regions where rainfall is either not sufficient to sustain a good crop and pasture growth or where, due to the erratic nature of precipitation, the risk of crop failure is very high. Water harvesting can significantly increase plant production in drought prone areas by concentrating the rainfall/runoff in parts of the total area. The intermittent character of rainfall and runoff and the ephemerality of floodwater flow require some kind of storage. There might be some kind of interim storage in tanks, cisterns or reservoirs or soil itself serves as a reservoir for a certain period of time (Finkel and Finkel, 1986). 
Water harvesting is based on the utilization of surface runoff; therefore it requires runoff producing and runoff receiving areas. In most cases, with the exception of floodwater harvesting from far away catchments, water harvesting utilizes the rainfall from the same location or region. It does not include its conveyance over long distances or its use after enriching the groundwater reservoir. Water harvesting projects are generally local and small scale projects (Pereira et al., 1994).

Aim of this study; management/conservation of stored water for optimum benefits can greatly enhance the effectiveness of water sustainability. Rainfed production systems in public parks are important to maintain the ecological balance. Green areas in the city are extremely effective for improvement of urban climate. Summer of Antalya province is quite hot. Because of this, the lawn area needs irrigated constantly, but water resources are decreasing. The use of rainwater is very important for protection of water resources. In this way, irrigation water amount used in Antalya Park's will be reduced. Thus, urban ecology will be protected with rain harvesting method. Mustafa Uysal Park, has been selected as study area for productivity of water harvesting in Antalya, Turkey.

\section{MATERIALS AND METHODS}

Mustafa Uysal Park is in Konyaaltı Antalya, on the east of Gazi Mustafa Kemal Street, on the southern of Uluç District and on the west of Uncalı District. Study area is $10 \mathrm{~km}$ away from the city of Antalya and adjacent to Konyaaltı beach. The park opened for use in 2008 and the total area is $4120 \mathrm{~m}^{2}$. This study is mainly focused on Mustafa Uysal Park (Figure 3).

Study method mainly based on two stages. These are field and office studies. The field studies have been conducted on 09/30/2013. In these detailed studies, the observations made for topographical,

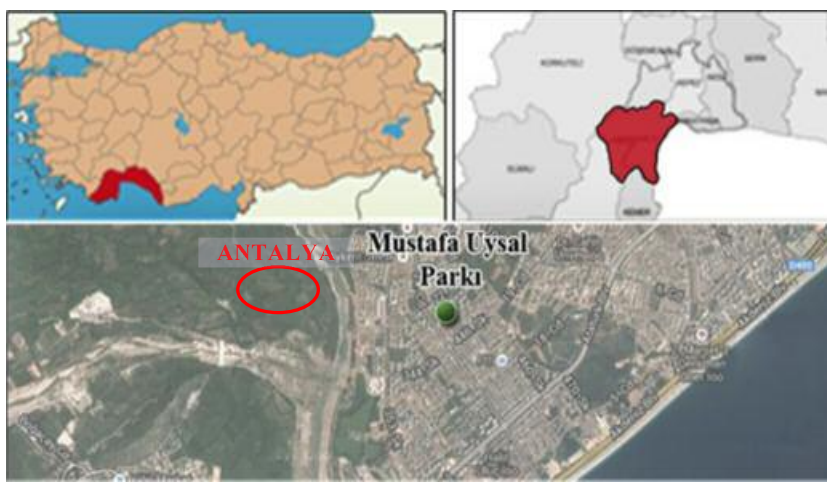

Figure 3. Location of study area in Turkey

Șekil 3. Çalıșma alanın Türkiye'deki konumu geological and visual analyzes, photos have taken and samples were collected for analyzing the general character of the vegetation.

For the case area, 1/25000 scaled topographical map (because at this scale topographic map taken from landsat website as free), land-cover analysis, vegetation maps and 52 years of Antalya climate data (1960-2012) have been used as materials. ArcGIS 10.1 software and Arc-Hydro tool have been used to determine water collecting micro-basins for Mustafa Uysal Park. Topography, slope and aspect analysis were created. Also, to figure out flow direction of rain water and water harvesting areas in park, we used "Arc-Hydro" extensions in ArcGlS software. After detecting drainage basins, using the rational method, the amount of runoff water has calculated.

Catchments, drainage lines and water collection points are determined in a very short time with ArcHydro plugin in Arc-GIS software. At first, topographic maps of lands should be digitized. 3-D terrain models should be established with this digitization maps. Catchment, drainage lines and water collection points determination process are carried out in two stages. The name of the first stage is "terrain data preprocessing". The second stage is "process of catchment". Working stage of the Arc-Hydro plugin is shown Figure 4. The blue areas in the figure show the inputs work. Yellow areas show processing. Green areas show output obtained from the processing.

Estimated net runoff formula has been used to determine water harvesting values for 12 months. The needs of water for irrigation and evaporation value for the surfaces have been calculated. With the use of these values, the amounts of water which can be stored have been determined. No tanks in the current situation in the study area. Areas with a minimum height value were determined for the tank as suitable location.

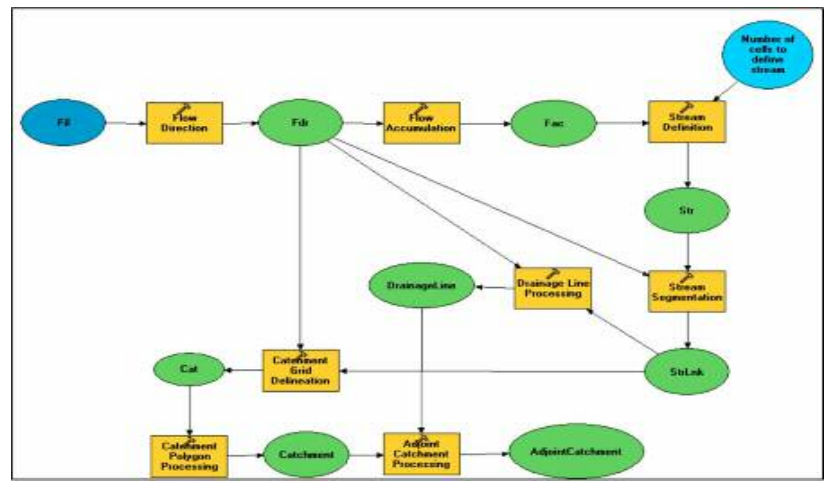

Figure 4. Working state of Arc-Hydro plugin

Șekil 4. Arc-Hydro eklentisi çalıșma așamaları 
For hydraulic designs on very small watersheds, a complete hydrograph of runoff is always required. The maximum, or peak, of the hydrograph is sufficient for design of the structure in questions. Therefore, a number of methods for estimating design discharges, that is, the maximum value of the flood runoff hydrograph have been developed (Thompson, 2006). For calculate the amount of runoff, Rational Method was used for this study.

The Rational Method can be traced back to the mid-nineteenth century. The use of the Rational Method in the urban environment has worked reasonably well in many countries. For rural catchments, the use of the Rational Method has received much criticism. Overseas researchers who have studied the method as a deterministic model and tested it with observed data have found that the method offers low accuracy when individual storms and resulting peak discharges are considered. However, studies by French et al., (1974), who examined the validity of the method, have shown that, statistically, the method serves the purpose of engineering practice, where peak discharges of a given frequency are linked with the rainfall intensities of the same frequency (Ismail and et al., 2010). Rational Method formula has been given as below, equation 1 (Thompson, 2006).

$$
\begin{aligned}
& Q=0,00277 . C \cdot I \cdot A \\
& Q=\text { maximum rate of runoff }\left(\mathrm{m}^{3} / \mathrm{sec}\right) \\
& C=\text { runoff coefficient representing a ratio of }
\end{aligned}
$$
runoff to rainfall

$$
C=R / P
$$$$
R=\text { Total depth of runoff (L) }
$$$$
P=\text { Total depth of precipitation (L) }
$$

I= average rainfall intensity for a duration equal to the tc $(\mathrm{mm} / \mathrm{hr})$

$A=$ drainage are contributing to the design location (ha.)

The runoff coefficient is a dimensionless ratio intended to indicate the amount of runoff generated by a watershed given a average intensity of precipitation for a storm. While it is implied by the rational method, equation 1, that intensity of runoff is proportional to intensity of rainfall, calibration of the runoff coefficient has almost always depended on comparing the total depth of runoff with the total depth of precipitation. The runoff coefficient represents the fraction of rainfall converted to runoff. Values are

\begin{tabular}{|c|c|c|c|}
\hline Description & Runoff Coefficient & Description & Runoff Coefficient \\
\hline & & Business & \\
\hline \multirow[t]{2}{*}{ Downtown Areas } & $0.70-0.95$ & Neighborhood Areas & $0.50-0.70$ \\
\hline & & Residential & \\
\hline Single-family & $0.30-0.50$ & Multi-family detached & $0.40-0.60$ \\
\hline Multi-family attached & $0.60-0.75$ & Residential suburban & $0.25-0.40$ \\
\hline Apartments & $0.50-0.70$ & Parks, cemetaries & $0.10-0.25$ \\
\hline Playgrounds & $0.20-0.35$ & Railroad yards & $0.20-0.40$ \\
\hline Unimproved areas & $0.10-0.30$ & Drives and walks & $0.75-0.85$ \\
\hline \multirow[t]{2}{*}{ Roofs } & $0.75-0.95$ & & \\
\hline & & Streets & \\
\hline Asphalt & $0.70-0.95$ & Concrete & $0.80-0.95$ \\
\hline Brick & $0.70-0.85$ & & \\
\hline & & Lawns; sandy soils & \\
\hline Flat, $2 \%$ slopes & $0.05-0.10$ & $\begin{array}{l}\text { Average, } 2 \%-7 \% \\
\text { slopes }\end{array}$ & $0.10-0.15$ \\
\hline Steep, 7\% slopes & $0.15-0.20$ & & \\
\hline Flat, $2 \%$ slopes & $0.13-0.17$ & $\begin{array}{l}\text { Lawns; heavy soils } \\
\text { Average, } 2 \%-7 \% \\
\text { slopes }\end{array}$ & $0.18-0.22$ \\
\hline Steep, $7 \%$ slopes & $0.25-0.35$ & & \\
\hline
\end{tabular}
tabulated in Table 1 (Thompson, 2006).

Table 1.General runoff coefficients for the rational method (Thompson, 2006)

Çizelge 1. Rasyonel yöntem için genel akıș katsayıları (Thompson, 2006) 
I= Average rainfall intensity for a duration equal to the the time of concentration (tc, $\mathrm{mm} / \mathrm{hr}$ ). Storm intensity (i), is a function of geographic location and design exceedance frequency (or return interval). It is true that the longer the return interval (hence, the lower the exceedance frequency), the greater the precipitation intensity for a given storm duration. Furthermore, the longer the length of the storm, the lower the storm average precipitation intensity. The relation between these three components, storm duration, storm intensity, and storm return interval, is represented by a family of curves called the intensity-duration frequency curves, or IDF curves. The IDF curves can be determined by analysis of storms for a particular site or by the use of standard meteorological atlases, such as TP-40 (1963) and HYDRO-35 (1977) (Thompson, 2006).

The intensity of the storm depends on the time of concentration (tc). The time of concentration of a watershed is often defined to be the time required for a parcel of runoff to travel from the most hydraulically distant part of a watershed to the outlet. It is not possible to point to a particular point on a watershed and say, "The time of concentration is measured from this point." Neither is it possible to measure the time of concentration. Instead, the concept of the time of concentration useful for describing the time response of a watershed to a driving impulse, namely that of watershed runoff. In the context of the rational method then, the time of concentration represents the time at which all areas of the watershed that will contribute runoff are just contributing runoff to the outlet. That is, at the time of concentration, the watershed is fully contributing. We choose to use this time to select the rainfall intensity for application of the rational method. If the chosen storm duration is larger than the time of concentration, then the rainfall intensity will be less than that at the time of concentration. Therefore, the peak discharge estimated using the rational method will be less than the optimal value. If the chosen storm duration is less than the time of concentration, then the watershed is not fully contributing runoff to the outlet for that storm length, and the optimal value will not be realized. Therefore, we choose the storm length to be equal to the time of concentration for use in estimating peak discharges using the rational method as the following equation 2 (Thompson, 2006). $\mathrm{tc}=1.12 *(1.1-\mathrm{C}) *(0.3048 * 1)^{1 / 2 *} \mathrm{~s}^{-1 / 3}$

(Altunkasa, 2002)

$L=$ The maximum length of the basin ( $m$ or feet)

$\mathrm{S}=$ Slope $(\mathrm{m} / \mathrm{m})$

$A=$ Drainage are contributing to the design location (ha)

\section{RESULTS AND DISCUSSION}

In the park, andesite was used as pavement. On the parking lot area concrete and asphalt, on the playground rubber was used as a pavement. Also, there is sand area. In the park which is not currently used. From the southwest to northwest Park slope is increasing. The study area is $34.6 \mathrm{~m}$ above sea level. Minimum elevation in the area is $40.82 \mathrm{~m}$ and maximum elevation in the area is $42.8 \mathrm{~m}$. Average elevation in the area is $41.3 \mathrm{~m}, 98.2 \%$ of the park is flat or slightly sloped, $1.3 \%$ is quite sloped and $0.49 \%$ is steep. There are 15 drainage basins according to flow direction of surface water in the park (Figure 5).

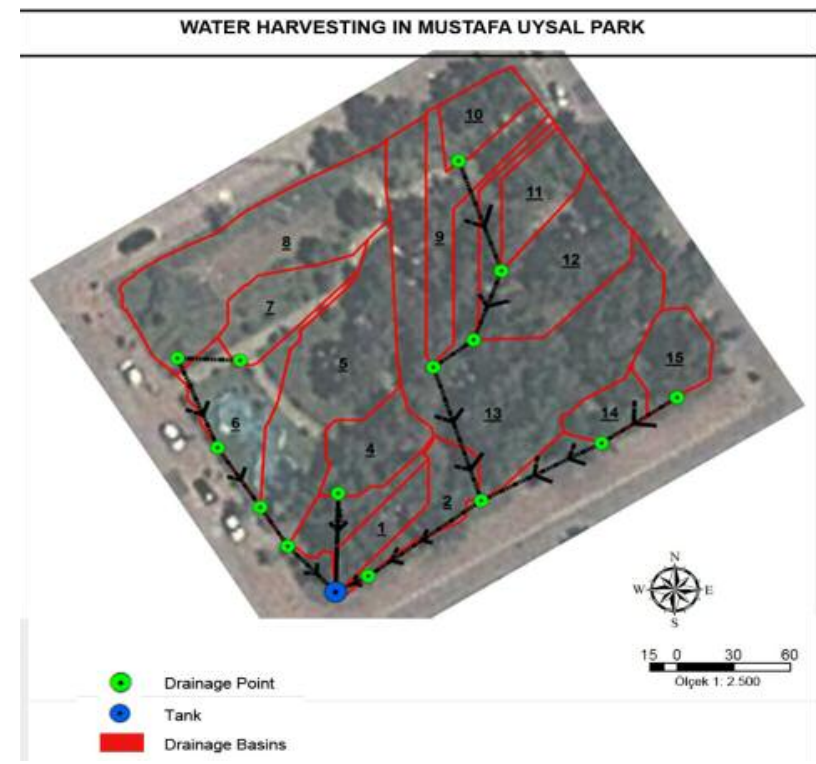

Figure 5. Mustafa Uysal park drainage basins

Sekil 5. Mustafa Uysal parkı drenaj havzaları

The biggest basin in $965 \mathrm{~m}^{2}$ and smallest one is $88 \mathrm{~m}^{2}$. After the water flow in drainage basin was specified, the water in drainage basin flow direction has detected. Number 1 basin in the park has $40.82 \mathrm{~m}$. elevation value and it is lower than all the other basins. That's why; this basin is going to be last stop for the surface water. According to seasons, the amount runoff water is changing. In 
Table 2. Rainfall data for Antalya city (1960 - 2015, kg.m²) (Antalya meteorological station)

Çizelge 2. Antalya ili için yağıș verileri (1960 - 2015, kg.m-2 (Antalya meteoroloji istasyonu)

\begin{tabular}{ccccccccccccc}
\hline Jan & Feb & Mar & Apr & May & June & July & Aug & sep & Oct & Nov & Dec \\
\hline 214.4 & 155.0 & 98 & 54.1 & 30.5 & 7.3 & 2.7 & 1.8 & 12.5 & 70.8 & 144.1 & 251.2 \\
\hline
\end{tabular}

Antalya especially in autumn and winter, there is been $1326.21 \mathrm{~kg} \cdot \mathrm{m}^{-2}$ rain water gather at the area in total (Table 2). Average rainfall amounts between 1960-2015 years were taken from Antalya meteorological station.

Calculations show that in winter (SeptemberFebruary) $131.42 \mathrm{~m}^{3}$ is evaporated. In calculating these values were used information about Evaluation of Amounts of Outdoor Surface Evaporation" belong to 2014 which taken General Directorate of Meteorology. In total $1627.50 \mathrm{~m}^{3}$ rain water can be gathered at the area. This amount is the $81 \%$ of the rain water in whole year. In spring and summer (March-August), the amount of water in the area is $302.50 \mathrm{~m}^{3}$. In these seasons, rain water in the area is totally evaporated (Table 3).

After the amount of rain water in the area is specified, the water need for irrigation is calculated. In the process of irrigation calculation, the size of park, monthly rainfall intensity and the upper cover (grass, asphalt, concrete) information's are used.

To find the water need per months park, we multiplied the days without rain, rainfall intensity and some specific coefficient. After the calculations, we determined that Mustafa Uysal Park needs $5392.20 \mathrm{~m}^{3}$ water during the summer and $1344.90 \mathrm{~m}^{3}$ water during the winter for a year's and $6744.04 \mathrm{~m}^{3}$ water as total.

\section{CONCLUSIONS}

Especially in last years, water harvesting is become very important issue for developing countries. For a new resource of water, water harvesting method is getting popular. When the water harvesting in rural areas consider social and economic impacts; water harvesting provides reliable and continuous water and offers new opportunities using the existing water (such as farming and agriculture). Increasing revenue with more job opportunities, reduced migration to urban from rural, so that rural areas further develops.

In this study, the amount of rain water in the area is calculated by using this method. The result of analyses showed that especially in winter, there is too much rain water detected at the park in Mustafa Uysal Park. Rain water in the area provides $20.8 \%$ of irrigation water need for a year.

Table 3. Estimated values of rainfall harvest in Mustafa Uysal Park (Antalya meteorological station)

Çizelge 3. Mustafa Uysal Park yağmur suyu hasatı tahmini değerleri (Antalya meteoroloji istasyonu)

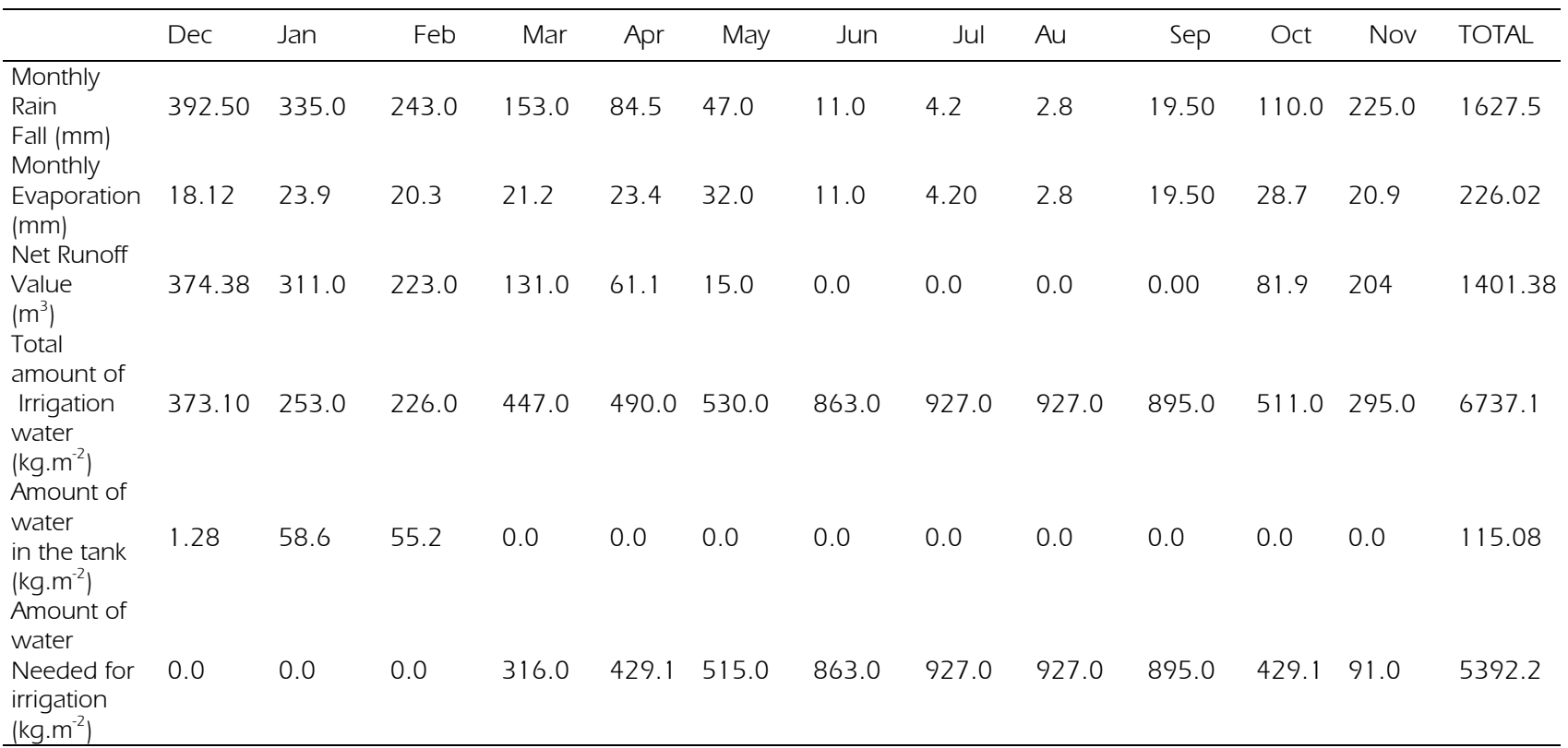


Efficient use of water in arid ecosystems includes effective irrigation system. For this purpose, irrigation system should be established suitable for purpose, size and the landscaping concept of area. Optimal irrigation system plans should have done for distribution and transmission of stored water. Water harvesting techniques should be developed for the place design by examining slope, climate, soil, land use and land cover purpose in the study area. The most important point for landscape design is use of native species as the planting design. Species such as Pinus halepensis, Juniperus sabina, Hedera helix. L. which are resistant to drought or require less irrigation, must be selected in areas with water problems.

Water harvesting methods should not use only land. Water harvesting methods can be made on the roofs of buildings. In this way, plants on the environment can be met needs of water. This method is very important in terms of urban ecology. Specific occupational groups should not do alone such subject. Such studies should be multidisciplinary. For example, landscape architecture, agricultural irrigation, construction engineer and ecologist. Study about water harvesting in Turkey has found this result. Due to water harvesting methods, reduced soil erosion and overexploitation of groundwater also provide the nutrition of groundwater. Because it allows the reforestation in the urban area, water harvesting method very important for protect trees.

The use of rainwater for irrigation is very important. Because of air pollution, characteristics of rainwater are changing. Therefore, Rainwater required analysis for use of irrigation. Studies supported this aspect. So, work about water harvesting is appreciated more scientifically. Countries have begun to appreciate the water harvesting method in recently. In this way, countries have begun to reduce the amount of their spent to irrigation system.

For example, Singapore, which has limited land resources and a rising demand for water, is on the lookout for alternative sources and innovative methods of harvesting water. Almost $86 \%$ of Singapore's population lives in high-rise buildings. A light roofing is placed on the roofs to act as catchment. Collected roof water is kept in separate cisterns on the roofs for non-potable uses. A recent study of an urban residential area of about 742 ha used a model to determine the optimal storage volume of the rooftop cisterns, taking into consideration non-potable water demand and actual rainfall at 15-minute intervals. This study demonstrated an effective saving of $4 \%$ of the water used, the volume of which did not have to be pumped from the ground floor. As a result of savings in terms of water, energy costs, and deferred capital, the cost of collected roof water was calculated to be S $\$ 0.96$ against the previous cost of $\$ \$ 1.17$ per cubic meter (United Nations Environment Programme, 2016).

Water harvesting can substantially increase rainwater productivity in the drier marginal environments. It is the only option for economic agricultural and environmental protection in these areas. Though technologies for various conditions are available, many of them are not widely adopted. This can be attributed to technical, socioeconomic and policy factors, but most importantly the lack of community participation in the development and implementation of these technologies (Oweis and Hachum, 2005). Water harvesting methods are very important in terms of sustainable use of water. Scientific studies about water harvest focus on agricultural-production, but the water is not only related to agriculture. Impacts of water on urban green space are not considered. Very few studies indicate the importance of water in terms of ecology. Water harvesting methods should be examined effect of water on ecology.

The advantages of water harvesting remain valid and designers have to utilize them for a sustainable water management. Researches about water harvesting in Semi-arid areas such as Antalya in Turkey will be helpful for optimal harvesting techniques, determination of required water harvesting structure and the selection of the most suitable plants. Thanks to the special design for water harvesting structures, urban tourism will develop and the city will increase revenue.

\section{REFERENCES}

Altunkasa M F (2002). Peyzaj Mühendisliği. Çukurova University, Agricultural Faculty. Çukurova Üniversitesi Ziraat Fakültesi Genel Yayın No: 123 Ders Kitapları Yayın No: A-36, Adana. pp: 366.

FAOSTAT (2012). Database. Food and Agriculture Organization (FAO), Rome. Accessed June 2012. http://faostat.fao.org/.

Finkel H J, Finkel M (1986). Engineering Measures: Water harvesting. In Finkel, H.J., Finkel, M. and Z. Naveh (eds). SemiArid Soil and Water Conservation. CRC Press, Inc., Boca Raton, Florida, USA.

Ismail B A (2010). Hydrological Procedure No: 5. Rational Method of Flood Estimation for Rural Catchments in Peninsular 
Malaysıa. Division Of Water Resources Management And Hydrology Department Of Irrigation And Drainage Ministry Of Natural Resources And Environment. pp: 19.

Oweis T, Hachum A (2005). Water harvesting and supplemental irrigation for improved water productivity of dry farming systems in West Asia and North Africa. Agricultural Water Management pp: 57-73.

Pereira L S, Feddes R A, Gilley J R, Lesaffre (1994). Sustainability of Irrigated Agriculture. NATO ASI Series, Advanced Science Institutes Series, Series E: Applied Sciences Vol.312. pp: 630

Rockstrom J, Folke C, Gordon L, Hatibu N, Jewitt G, Penning de Vries, $F$, Wehumbiza $F$, Sally $H$, Savenije $H$, Schulze R (2004). A watershed approach to upgrade rainfed agriculture in water scarce regions through water system innovations: an integrated research initiative on water for food and rural livelihoods in balance with ecosystem functions. Physics and Chemistry of the Earth 29:1109-1118.

Rockström J, Lannerstad M, Falkenmark M (2007). Assessing the water challenge of a new green revolution in developing countries. Edited by William A. Jury, University of California, Riverside, CA. Current Issue, vol. 104 no. 15, 62536260, doi: 10.1073/pnas.0605739104.

Rockstrom J (2000). Water resources management in smallholder farms in Eastern and Southern Africa: an overview. Physics and Chemistry of the Earth 25(3):275-283.
Scheierling M S (2011). Towards an agenda for improving wastewater use in agriculture. Water International, 36:4, 420440, DOI: 10.1080/02508060.2011.594527.

Studer R, Lineger H (2013). Water Harvesting Guidelines to Good Practice. Centre for Development and Environment (CDE) and Institute of Geography, University of Bern; Rainwater Harvesting Implementation Network (RAIN), Amsterdam; MetaMeta, Wageningen; The International Fund for Agricultural Development (IFAD), Rome. pp: 210.

Thompson D (2006). The Rational Method. David B. Thompson Civil Engineering Department Texas Tech University. pp: 1-7

United Nations Environment Programme (2016). An Environmentally Sound Approach for Sustainable Urban Water Management: An Introductory Guide for Decision-MakersExamples of Rainwater Harvesting and Utilisation Around the World. Available: http://www.unep.or.jp/ietc/publications/urban/urbanenv2/9.asp

Waterfall H P (2004). Harvest Rainwater for Landscape Use. Cooperative Extension.

College of Agriculture and Life Sciences The University of Arizona Tucson, AZ 85721. pp: 53. 